\title{
THE CORONAVIRUS CRISIS AND MIGRATION: THE PAN-SYNDEMIC AND ITS IMPACT ON MIGRANTS
}

\author{
Fabio PEROCCO
}

COBISS 1.01

\begin{abstract}
The Coronavirus Crisis and Migration:

The Pan-Syndemic and Its Impact on Migrants

The coronavirus crisis exposed and exacerbated inequalities that already existed. Simultaneously, it has transformed inequalities, changing old ones, generating new ones, intertwining the old and the new. A test of these processes, in particular, of the differentiated impact of the health crisis, may be observed in migration. After examining the ecological-social origins of the novel coronavirus and the COVID-19 related racial health inequalities, the article analyzes the consequences of the pandemic on the health and working conditions of immigrant workers, asylum seekers, emigrants in travel. It highlights the syndemic situation affecting them.
\end{abstract}

KEYWORDS: coronavirus, inequalities, migration, pandemic, syndemics

\section{IZVLEČEK}

\section{Koronakriza in migracije: Pansindemija in njen vpliv na migrante}

Koronakriza je že obstoječe neenakosti še poudarila in povečala. Hkrati jih je tudi preoblikovala, spremenila stare, povzročila nove ter prepletla stare in nove. Te procese, zlasti diferenciran vpliv na zdravstveno krizo, je mogoče opazovati pri migracijah. Članek uvodoma analizira ekološko družbeni izvor novega koronavirusa in z njim povezanih rasnih zdravstvenih neenakosti, nadaljuje pa z obravnavo posledic pandemije na zdravje in delovne razmere migrantskih delavcev, prosilcev za azil in migrantov na poti. Osvetljuje sindemično situacijo, v kateri so se znašli.

KLJUČNE BESEDE: koronavirus, neenakosti, migracije, pandemija, sindemija 


\section{THE ECOLOGICAL-SOCIAL ORIGINS OF SARS-COV-2}

This article, based on the study of the literature and secondary resources, aims to analyze the consequences of the COVID-19 pandemic on the health and working conditions of immigrant workers, asylum seekers, emigrants in travel. Before this, I examine some fundamental aspects such as the origins of the novel coronavirus, the social impact of this pandemic, the COVID-19 related racial health inequalities.

It is now accepted that the 2019 novel coronavirus (SARS-CoV-2) - which is the result of the spillover of a bat virus (Burgio 2020) causing a very serious, often lethal, disease in humans: COVID-19 (COronaVIrus Disease2019, acute respiratory disease from SARS-CoV-2) - has ecological-social origins. This fact is nothing new since most epidemics have been the result of major environmental and climate changes, partly and sometimes linked to human activity.

Such origins are manifold and have a name: climate changes, environmental disruption, deforestation, agribusiness, mass urbanization. Better yet: capitalism's attack on man and nature. If the novel coronavirus is a symptom of a progressive disease affecting the biosphere, this disease results from the ecological rift produced by the capitalist economy (Foster et al. 2011). The emergence of "new" pathogens and the resulting pandemics is not random. There are specific and structural causes: let's see.

Wallace (2016) points out that the emergence of new dangerous viruses is linked first and foremost to the processes of deforestation and human penetration into the last primary forest. Land-grabbing, the disappearance of small-scale agricultural land working for the local market, and extractivism in the primary forest release new pathogens that for millennia have been held in check by the forest ecosystem. The irruption of agri-business into virgin ecological systems brings pathogens out of the deepest hinterland. Through some reservoir-species (birds, bats, etc.), they are transported out of the forest into neighboring, peri-urban areas where human settlements and livestock are present, with the consequence that "the functional diversity and complexity these huge tracts of land represent are being streamlined in such a way that previously boxed-in pathogens are spilling over into local livestock and human communities" (Wallace 2020: 33). Besides, the impoverishment of local communities is forcing local people to go even deeper into the remote forest to collect food (wildlife), thereby increasing their encounters with new pathogens. After that, the passage to urban peripheries, to big cities, through the internal and international movements of things, animals, and men, is a relatively easy thing to do; the globalization of world trade and international migration do the rest, in the sense that they facilitate, feed, and widen the circulation and spread of the virus. Still, in these exchanges and passages of environments and hosts, pathogens mutate and develop more virulent and infectious phenotypes.

Deforestation and forest penetration are closely linked to the industrialization of agriculture, in which hyper-intensive, concentration-based animal production 
constitutes, Wallace points out, a nursery for more or less dangerous viruses, a veritable breeding ground for zoonosis (Andersen et al. 2020):

Growing genetic monocultures of domestic animals removes whatever immune firebreaks may be available to slow down transmission. Larger population sizes and densities facilitate greater rates of transmission. Such crowded conditions depress the immune response. High throughput, a part of any industrial production, provides a continually renewed supply of susceptibles, the fuel for the evolution of virulence. (Wallace 2020: 34)

In destroying ecosystems, agri-industry pools together living beings expelled from their natural habitat with intensive livestock farming; these contacts are the source of spillover of viruses - which are not coincidentally given animal names (swine, cattle, avian). At the margin of agri-business, the incubation of coronaviruses (MERSCov, SARS-CoV, SARS-CoV-2) takes place.' Referring, for example, to the recurrent Ebola epidemics in Africa, Wallace notes the continuity of the link between the expansion of primary industries, the penetration of agribusiness, the destruction of local eco-systems, the displacement of populations, the attraction of reservoir species, and epidemics. While there was a cotton-related outbreak in Sudan in the mid-1970s (Wallace, Wallace 2016: 60), in recent years, palm oil industrialization appears to be responsible for recent Ebola outbreaks in Guinea (Wallace et al. 2016; Wallace, Wallace 2016).

Moreover, ever greater masses of the human population live in highly degraded environmental and rural contexts or are crowded into the suburbs of large cities. This factor is certainly not a primary cause, but it is a factor that facilitates the stabilization and circulation of viruses. In China, SARS-CoV-2 was born at the intersection of capitalist economics and epidemiology (Chuăng 2020); Wuhan (11 million inhabitants), Chongqing (36 million inhabitants), Nanjing ( 8.5 million inhabitants), Changsa (7 million inhabitants), are "four furnaces" below which there is an evolutionary pressure cooker made of hyper-urbanization and agri-business. Therefore, the latest great epidemics (avian flu, SARS-CoV, SARS-CoV-2) originated in China not so much because of some mysterious Chinese specificity, but rather because, in this country, the historical and social conditions for the emergence of these phenomena have concentrated in recent decades.

\section{THE GREAT EQUALIZER? COVID-19 AND INEQUALITIES}

The double - economic and ecological - crisis, predating the novel coronavirus, is accompanied by the health crisis, combining in a triple crisis that has affected all

1 On the roots of $\mathrm{H}_{5} \mathrm{~N}_{1}$ see Wallace (2016). 
spheres of the social life of the populations and the countries of the world, and that has had multiple consequences on the economic, social, political, and cultural levels. The health crisis has affected social classes, economic sectors, professions, genders, and countries differently. The assertion that the virus is a great equalizer is not true: the possibility of contracting it, COVID-19 prevention and treatment, its severity and mortality, daily life at the time of the pandemic, are elements related to social class, to the position in the social structure and system of social relations.

As for virus transmission, wealthy classes had a lower risk of becoming infected by enjoying the possibility of protecting themselves more and better or keeping a physical distance (availability of big houses, private cars, devices, paid services). During the lockdowns of the first wave, people in many countries were told to "stay home," but housing conditions are quite unequal - some people live in crowded, small houses with little equipment, and some people have no house at all. In terms of exposure to the virus, a large proportion of the working class could not avoid going to work, could not work from home as they were employed in essential jobs (shop assistants, nurses, cashiers, public transport, cleaning or personal care workers), could not work in a protected manner; for these categories of workers, exposure to the virus was particularly strong and prolonged. Working-class and deprived groups were found to have more susceptibility to COVID-19 due to worse social, economic, and environmental conditions. The resources available within the storm of the pandemics have been differentiated and unequal: it is not true that "we are all in the same boat," if anything, we navigate rough seas with very different boats; some people do not even have a boat at all.

\section{Syndemics and Health Inequalities}

COVID-19 has more severely affected the elderly and individuals suffering from chronic diseases (diabetes, cardiovascular disorders, tumors, diseases of the immune system). However, such diseases are often the result of inequalities in the social determinants of health. They are linked to social factors (profession, income, education), the living conditions of the individual, their class condition. Thus, not only the possibility of contracting the virus but also the possibility of suffering serious complications or dying from COVID-19 is linked to the position occupied in the social structure. This position is manifested in the social gradient of health and affects the vulnerability to COVID-19.

Gravlee (2020: 1-2), while recalling that "pandemics always follow the fault lines of society," underlined that COVID-19 presented the conditions of a syndemic (Singer 2009), ${ }^{2}$ which is the result of the combination of disease concentration ("the

2 "The presence of two or more disease states that adversely interact with each other, negatively affecting the mutual course of each disease trajectory, enhancing vulnerability, and which are made more deleterious by experienced inequities" (The Lancet 2017: 881). 
co-occurrence or clustering of multiple epidemics as a result of large-scale, political-economic forces and adverse social conditions") and disease interaction ("the ways that overlapping epidemics exacerbate the health effects of adverse social conditions, either through biological interactions between disease states or through interactions between biological and social processes"). With COVID-19 there was a syndemic - "a set of closely interrelated endemic and epidemic conditions (e.g., HIV, TB, STDs, hepatitis, cirrhosis, infant mortality, drug abuse, suicide, homicide, etc.), all of which are strongly influenced and sustained by a broader set of political-economic and social factors" (Singer 1996: 99) - resulting from the interaction between infectious disease (contracted differently according to the social gradient) and noncommunicable diseases (unequally distributed according to the social gradient). Thus, as it has happened in the past and recently during other influenza epidemics (Mamelund 2019), COVID-19 affected the population differentially; morbidity and mortality were unevenly distributed across class, race, gender, age, territory. ${ }^{3}$

\section{COVID-19 and Racial Inequalities}

Many studies have confirmed that the unequal impact of COVID-19 on population health is related to the "race" factor, to racism. Everywhere racial inequalities in health emerged for COVID-19, which are the result of systemic racism and structural racial inequality. I will quickly dwell on two contexts: the United States and Brazil.

Gravlee noted a peculiar syndemic situation in the United States. In terms of social factors, racism had significant weight on the health impact of COVID-19, with somewhat worse consequences for the African-American population. The historical condition of social inferiority of black people has been the humus in which the COVID-19 syndemic has developed, characterized by a more severe COVID-related health condition among blacks (but also among Latinos and Native Americans). The racism that structurally pervades the US society (from work to income, from education to the judicial system, from housing to urban planning, even to the air we breathe - Novick 1995) has constituted "a fundamental cause of racial inequities in disease concentration. This perspective sees the social patterning of hypertension, diabetes, and now COVID-19 as culminating from a system of racial oppression" (Gravlee 2020: 4). Laster Pirtle emphasized the importance of structural racism in COVID-19's production of differential effects, of heavier consequences for blacks: "Racism and capitalism mutually construct harmful social conditions that fundamentally shape COVID-19 disease inequities because they [...] replicate historical patterns of inequities within pandemic" (Laster Pirtle 2020: 504).

In a country where access to health care is class-based and where even before the pandemic, there was exponential growth in the level of worker indebtedness

3 For the UK see Sage (2020), for Italy see Istat (2020a, 2020b). 
due to healthcare costs, infections and COVID-19 mortality were characterized by racial disparities (Bassett et al. 2020; Chin-Hong et al. 2020; Zelner et al. 2020), already at the start of the pandemic (Barbieri 2020). This trend continued even more sharply in the months that followed: through mid-August 2020, there were 2.6 more cases among African Americans than among the white population, 4.7 more hospitalizations, and 2.1 more deaths ${ }^{4}$ (CDCP 2020). The second wave saw a worsening of mortality disparity, with "Black, Indigenous and Latino Americans all have a COVID-19 death rate of triple or more White Americans, who experience the lowest ageadjusted rates." ${ }^{\prime 5}$ Over-represented in essential, low-skilled, dangerous and demeaning jobs, African-Americans - most affected by COVID-19 - are also most affected by diabetes, cancer, and cardiovascular disease; they died more from COVID-19 and these diseases, i.e., from pre-existing comorbid conditions (syndemics).

In Brazil, the colonial, slave, and racist past of this country is alive more than ever and is still ingrained in its social structure and daily life (Fernandes 2008; Moura 1988). Deep racial inequalities are still present today and affect black and brown people, Indigenous populations at all levels: access to the labor market, jobs, unemployment rates, incomes, health status, and housing (Gonçalves 2018; Heringer 2002; Paixão et al. 2010). Whites hold $70 \%$ of managerial positions. The relative poverty rate is $15.4 \%$ among whites and $32.9 \%$ among blacks and browns (lbge 2019). This racial system has been reflected in COVID-19 infection and mortality: higher levels of COVID-19 infection and mortality have been reported among the black population (Baqui et al. 2020; Goes et al. 2020; Oliveira et al. 2020; Santos et al. 2020), which is highly present in essential and informal jobs. A study of 29,933 cases registered up to May 18, 2020, found a mortality rate of $55 \%$ among blacks and browns and $38 \%$ among whites, across all age groups and education levels; a gradual decrease in mortality rate as education level increases; a mortality rate of $80 \%$ among unschooled blacks and browns versus a mortality rate of $19 \%$ among whites with higher education (Batista et al. 2020). The largest epidemiological study conducted in the country found that the poorest populations (including Indigenous people, who have long been experiencing an increase in cardiovascular and metabolic diseases) are twice as likely to become infected compared to the richest population (Hallal 2020). Poorer regions (Nordeste, Norte and Centro-Oeste) had higher mortality rates. ${ }^{6}$

4 https://www.cdc.gov/coronavirus/2019-ncov/covid-data/investigations-discovery/hospitalization-death-by-race-ethnicity.html\#footnote01; https://covidtracking.com/race. Data as of 18 Aug. 2020.

5 https://www.apmresearchlab.org/covid/deaths-by-race\#counts (data updated 22 Dec. 2020). 


\section{THE CONSEQUENCES OF CORONAVIRUS CRISIS ON MIGRANTS}

The coronavirus crisis exposed the social problems and inequalities that already existed while at the same time amplifying and reinforcing them. It is accepted that it has sharpened social polarization within countries and global inequalities. It has increased inequalities in employment, economy, education, consumption, use of time, hitting harder the working class, women, young and older people, minorities. The coronavirus crisis has also transformed inequalities and the system of inequalities, changing old ones, generating new ones, intertwining the old and the new. A test of these processes, in particular of the differentiated impact of the crisis, can be observed in migration. Just as in the great economic crisis of 2008, during the pandemic, migrants suffered heavy consequences due to the double penalty of migrants, their dual status as wage earners and foreigners. They experienced conditions and problems similar to those of the native population, yet often more severe. As will be seen, for many reasons, migrants have been particularly vulnerable to the pandemic and its economic and social effects; specifically, because of their specific condition, they have a high level of exposure, susceptibility, and vulnerability and at the same time have suffered serious consequences at the labor and administrative levels, just to mention a few.

\section{Immigrant Workers: More Exposed, More Precarious, More Exploited}

Let's see in detail the impact of the coronavirus crisis on some dimensions of migrants' social life, distinguishing between immigrant workers residing in a foreign country, asylum seekers, emigrants in travel.

Concerning the former, two points must be made. Firstly, they reside mainly in the large urban and industrial centers of Europe, the Americas, Southeast Asia and the Gulf, in other words, in the most populated and crowded areas of the planet. According to the IOM in 2014, about twenty percent of international migrants lived in twenty major cities (from London to New York, Shanghai to Buenos Aires), where they accounted for a fifth of the population (but they were $83 \%$ in Dubai, $62 \%$ in Brussels, $46 \%$ in Toronto ${ }^{8}$ ). Secondly, they constitute an essential part of the workforce employed in key-sectors; in 2017, they constituted $20.6 \%$ of workers in North America, $17.8 \%$ of workers in Northern, Western, and Southern Europe, $40.8 \%$ of workers in the Arab States (Ilo 2018: XII), primarily employed in low-skilled, dangerous, demeaning but essential jobs for so many economic sectors: logistics, transport, business

7 On risk factors and areas of vulnerability see OECD (2020a).

8 https://migrationdataportal.org/themes/migration-data-relevant-covid-19-pandemic (data updated 23 Nov. 2020). According to the IOM, as of November 3, 2020 immigrants "accounted for at least $4.5 \%$ of the population in 12 of the 20 countries with the highest number of COVID-19 cases, and this share is more than $10 \%$ in 8 of these countries." 
and personal services (riders, retail, cleaning, domestic and care work), healthcare, the tourist-hotel and restaurant sectors, construction, food processing, agriculture. Low-skilled immigrant workers are over-represented in several essential jobs; in Europe, about thirteen percent of key workers are migrants (Extra-EU migrants or EU mobile citizens), but in some jobs such as cleaners or helpers, they account for more than a third (Fasani, Mazza 2020: 1, 10); in the United States,

sixty-nine percent of all immigrants in the US labor force and $74 \%$ of undocumented workers are essential workers [...] the percentage of undocumented essential workers exceeds that of native-born essential workers by nine percentage points in the 15 states with the largest labor force. In the ten largest MSAs, the percentages of undocumented and naturalized essential workers exceed the percentage of native-born essential workers by 12 and 6 percent, respectively. (Kerwin, Warren 2020: 1)

Due to their specific position in the labor market and their professional status, but in particular, due to their concentration in essential sectors and manual jobs, most immigrant workers were not able to work remotely, they were not able to abstain from work, they had to accept any working conditions to safeguard their residence permit or their job, they worked in places where anti-COVID precautions were not always applied, they continued to perform jobs characterized by close contact with colleagues or the public. Due to their general condition, they often use public transport and live in poor and densely populated areas, in dwellings with limited overcrowded spaces in which children, parents, grandparents, and uncles live together. For these reasons, they had high exposure to the virus, which more than a few times resulted in a high level of infection, concentrated in outbreaks that broke out in specific workplaces such as slaughterhouses, logistics hubs, food companies. This situation was compounded by a significant susceptibility resulting from general living and health conditions (syndemic).

At the moment, data on the diffusion of COVID-19 among immigrants is limited, inhomogeneous, and difficult to compare, also because of the different survey systems and demographic compositions. Nevertheless, we do have some initial indicative studies. In Sweden (Valeriani et al. 2020: the study covers the period March 13May 7,2020 ) and in Norway, ${ }^{9}$ twice the incidence of COVID-19 was reported among the immigrant population compared to the native population. In Spain (Guijarro et al. 2020), in France (Papon, Robert-Bobée 2020), in the Netherlands (Kunst et al. 2020: 14), in Sweden (Hansson et al. 2020), the significant susceptibility to the virus produced by general living conditions and difficulties in accessing health services ${ }^{10}$ has resulted in medical complications and sometimes excess mortality among the

9 University of Bergen, https://www.uib.no/en/globalchallenges/139119/being-healthy-andworking-new-country (22 Nov. 2020). Due to language difficulties, lack of residence permit, etc. 
immigrants. In Italy, a national study updated to April 2, 2020, has highlighted that the casuistry regarding foreign-born people presents a different demographic and clinical structure from the casuistry of those born in Italy. Among the former, the female component is higher ( $56.4 \%$ vs. $50.8 \%$ ), the average age is lower (46 years vs. $64)$, there is a greater concentration in the northwest $(72.8 \%$ vs. $57.5 \%)$ and urban areas (52.1\% vs. $31 \%$ ). Above all, there is a higher risk of hospitalization and admission to intensive care (1.4 times). There are more severe manifestations of the disease even in terms of age - due to delays in diagnosis and the use of health services (Idos 2020: 251).

As was the case with the economic crisis ten years ago, the coronavirus crisis has had a harsh impact on the work of immigrants, who have been among the hardest hit by precarity, unemployment and underemployment, worsening working conditions, and impoverishment. Although the impact on the employment of all workers has been heterogeneous, in the OECD area, the worst consequences have fallen on immigrant workers (OECD 2020b: 11-12) for several reasons: the strong presence in sectors affected by the crisis (hotel, restaurant, domestic work) or in sectors with a high level of informality, irregularity, and precarity; the concentration in low-skilled jobs, the first to be affected in times of recession and unemployment; an often unstable administrative condition, deriving from the link between work contract and residence permit; partial fruition of social rights, as they are linked to the migratory status. Workers who are structurally precarious by definition and de facto, precisely because of their concentration in precarious jobs, have been among the first to be affected by unemployment and more acute precariousness, falling into a kind of "precarity loop." Moreover, the pandemic has enlarged and amplified their overeducation and under-classification. In the context of high unemployment, to find or keep a job enabling them to obtain or renew their residence permit, immigrants have been forced to accept a lower classification. In some national contexts, they were penalized for enjoying social safety nets, and there have been cases of discrimination in welfare.

As far as unemployment is concerned, Hispanic women in the US $(-21 \%$ compared to other women or men), immigrants (-19\% compared to 12\% US-born), young adults and the less educated were most affected by job loss (Kochhar 2020); immigrants - especially Latinos and women - were more acutely affected by unemployment than US-born citizens (16.5\% vs. $14 \%$; Capps et al. 2020). In Canada, in MarchApril 2020, recent immigrants - who are concentrated in short-term, low-paying jobs - were more affected by unemployment than Canadian-born workers and long-term immigrants (job-to-unemployment transition rates of $17.3 \%, 13.5 \%$ and $13.5 \%$, respectively; Hou et al. 2020). The impact on the employment of immigrant women (regardless of education level) was particularly harmful. Between March and May 2020, the unemployment rate for immigrant women increased by about 
7\% compared to $4.5 \%$ for Canadian-born workers and immigrant men. ${ }^{11}$ In Germany, unemployment grew faster among immigrant workers in March-June 2020 (27\% vs. $20 \%)^{12}$

In some economic sectors or geographical contexts, there have been situations of worsening exploitation of workers, of exacerbation of discrimination at work. In Italian agriculture, the area of severe labor exploitation has widened, working conditions have worsened with the increase in irregular work, the lengthening of working hours, the intensification of work rhythms, the reduction of wages and break times, the reduction of labor disputes (Idos 2020: 289). ${ }^{13}$ In Spain, in the agricultural sector of Huelva, female farmworkers from a bleak pre-COVID condition have plummeted into a hellish condition. ${ }^{14}$

\section{Asylum Seekers between Confinement and Abandonment, and the Migrant Odyssey}

During the pandemic, asylum seekers suffered severe consequences - at the health and social level - due to their structural vulnerability and poor social status, which predated the pandemic. There are no systematic and updated data on infections among asylum seekers. However, various sources (specialized organizations, press, etc.) indicate that the reception centers and refugees camps were not able to ensure physical distance and public health; the crowding of the centers and refugees camps was, if anything, a significant factor of contagion. The dramatic case of the Moria camp in Lesbos, between COVID-19 and detention, was one of the darkest pages of the refugee tragedy and an example of the inadequacy of the camp model. Not only because these facilities are severely overcrowded and it is not possible to maintain distancing, but also because very often, the infected were not evacuated from the facilities and were quarantined within them, spreading the virus to the entire facility.

This type of management has occurred more than a few times in Italy. With the dismantling of the widespread reception system and the concentration of asylum seekers in large reception centers, the ground has been prepared for spreading the virus. A study carried out in June 2020 on 195 reception centers scattered throughout the country highlighted that the management of PCR-positive guests very often implied the adoption of uneven and improvised measures with DIY solutions. ${ }^{15}$

11 https://policyoptions.irpp.org/magazines/october-2020/the-startling-impact-of-covid-19on-immigrant-women-in-the-workforce/ (22 Nov. 2020).

12 https://www.reuters.com/article/idUSL5N2EZOXS (22 Nov. 2020).

13 A journalistic investigation has documented a worsening of the conditions of foreign laborers in several European countries; https://www.euronews.com/2020/07/17/invisible-workersunderpaid-exploited-and-put-at-risk-on-europe-s-farms (22 Nov. 2020).

14 https://www.openglobalrights.org/protecting-migrant-women-workers-in-food-supplychains-during-covid (22 Nov. 2020).

15 https://www.redattoresociale.it/article/notiziario/covid19_prassi_fai_da_te_improvvisate_e_difformi_ecco_cosa_e_successo_nei_centri_d_accoglienza (22 Nov. 2020). 
Using a special "saturation index" of reception centers, another national study conducted on 5,038 facilities between May-June 2020 confirmed the close correlation between overcrowding and risk of infection. The same study showed that the isolation of positive subjects ordered by the health authority took place in a quarter of the cases at the same facility. Only half of these cases were in a single room with exclusive services (Costanzo et al. 2020).

Often, and in many parts of the world, to add insult to injury, the victim-blame effect applied: these structures and their "guests" have been singled out as spreading the epidemic, the carriers of the virus. Thus, to the traditional public image of the asylum seeker as a slacker, scrounger, and underdeveloped, the element of "asylum seeker as a health hazard" was added. With the pandemic, we witnessed the appearance - not new - of the link between otherness - health emergency - security policies, which was followed by exclusion practices and racism in the name of health security (also through the distinction between "native virus" and "foreign virus").

There are still no systematic studies on the impact of the pandemic on the work of asylum seekers. Yet, from various sources (reports, press articles, etc.), it has emerged that in many parts of the world, people seeking asylum have lost their jobs, have had great difficulty finding new ones, and have seen an increase in irregular work. This situation led to an increase in inactivity and monotony in reception centers, especially during lockdown periods when these facilities became veritable prisons in which inactivity, discouragement, forced overcrowding, and a sense of abandonment took over. On the other hand, those who did not lose their jobs faced the problem of a high risk of infection by being employed in low-skill jobs in essential sectors.

In addition to the loss of jobs, there was the uncertainty of their residence status due to: the suspension of asylum applications and residence permits, the weakening of legal status caused by the state of emergency, the closure of borders and humanitarian corridors, the interruption of the provision of reception and integration services (especially during lockdowns), the absence of specific interventions in favor of this category in times of pandemic, the problematic access to social and health services and inadequate health care at a time when the health systems of many countries have been in crisis. All this further aggravated a situation that was already compromised and deteriorated by forced migration, poor mental and physical conditions due to the journey and life in the camps, repressive and punitive migration policies, and the anti-migrant propaganda that has long raged throughout a large part of the world. These elements have negatively affected their exposure to the novel coronavirus. They have damaged the first steps of integration and rooting, throwing thousands of people into limbo and negatively impacting those who have not obtained humanitarian protection or asylum and those who have left the reception and international protection systems, especially undocumented.

With the arrival of the pandemic, almost all the countries of the world (about 195) closed their borders, strengthened controls, imposed more restrictions. If most of the time these measures were due, sometimes the pandemic was a pretext to 
apply ultra-restrictive measures and migration policies not justified by the pandemic. Of course, these elements have reduced migratory movements and limited departures. However, since the causes of emigration have not changed - on the contrary, with the coronavirus crisis, they have become even more profound in poor countries - emigration has continued, albeit in a more difficult, more uncomfortable, more dangerous, and more costly manner.

The closure of borders, ports, ${ }^{16}$ and legal channels, the worsening migration policies, and health restrictions have aggravated migration conditions for both those already on their way and those setting out during the pandemic. More than a few times, migrants have been stranded in transit countries, at border crossings, along the way, stranded with no means of livelihood, little access to services, with little public attention. The worsening conditions of migration have made them even more vulnerable; with the pandemic, they have seen an increased risk of inhuman treatment and have suffered escalated mistreatment, rape, violence. The reports and documentation regarding migration in different parts of the world - for example, the Colombian-Venezuelan area, Central America, the Mexico-US border, India, the Balkan route, the sub-Saharan route, the Mediterranean route - have painted a gloomy picture; a large part of the migrations have slipped into a foggy limbo, passing even more into the hands of traffickers and criminal organizations that have often operated undisturbed. In the situation of closed borders, forced vacuum (the absence of NGOs, journalists, rescues, public authorities), and state of emergency, migrations have become even more irregular, new services related to smuggling have arisen, smuggling activities have changed adapting to the new context, traffickers have changed routes and modes adapting to the new situations, finding new solutions (Sanchez, Achilli 2020).

\section{CONCLUSION}

The coronavirus crisis has taken place in the context of structural growth of inequalities in the four corners of the planet in recent decades. A context in which all forms of inequality have become more acute. Inequalities have been modified and exacerbated because of the considerable ongoing environmental crisis and the deep ecological rift - which, in combination with the acute economic crisis and the SARSCoV-2 health crisis, have unified into a colossal triple crisis of contemporary society.

The pandemic has aggravated racial inequalities. Racialized groups were strongly penalized by it in all spheres of social life. Some social groups, such as emigrants and immigrants, who were already highly vulnerable and disadvantaged, have been hit very hard by their dual status as wage earners and foreigners. Many migrant women

16 In the Mediterranean, quarantine ships have also been added, fully-fledged floating hotspots on which hundreds of people have been kept at sea for days on end. 
have seen their living and working conditions worsen dramatically due to the triple oppression that constantly weighs on them.

The pandemic has exposed the role and the condition of migrants within the world labor market, the nature of migration policies, the utilitarian (or pathological) conception of immigration in many countries. For this reason, the coronavirus crisis could be - and should be - an opportunity to rethink migration policies, to review the dominant conception of the immigrant as a man/woman bearer of needs for social emancipation.

\section{REFERENCES}

Andersen, Kristian et al. (2020). The Proximal Origin of SARS-CoV-2. Nature Medicine $26,450-452$.

Baqui, Pedro et al. (2020). Ethnic and Regional Variations in Hospital Mortality from COVID-19 in Brazil. The Lancet 8/8, 1018-1026.

Bassett, Mary et al. (2020). Variation in Racial/ethnic Disparities in COVID-19 Mortality by Age in the United States. PLoS Med 17/10, 1-14.

Batista, Amanda et al. (2020). Análise socioeconômica da taxa de letalidade da COVID-19 no Brasil. NOIS, https://sites.google.com/view/nois-pucrio/publica\%C3\%A7\%C3\%B5es (12 Oct. 2020).

Burgio, Ernesto (2020). Rapporto su una pandemia (inutilmente) annunciata. Pandemia nel capitalismo del XXI secolo (eds. Alessandra Ciattini, Marco Pirrone). Varazze: PM, 21-42.

Capps, Randy et al. (2020). Covid-19 and Unemployment: Assessing the Early Fallout for Immigrants and Other U.S. Workers, Washington DC: Migration Policy Institute; https://www.migrationpolicy.org/research/covid-19-unemployment-immigrants-other-us-workers (12 Oct. 2020).

CDCP (2020). COVID-19: Hospitalization and Death by Race/Ethnicity, https://www.cdc. gov/coronavirus (12 Oct. 2020).

Chin-Hong, Peter et al. (2020). Pulling at the Heart: COVID-19, Race/ethnicity and Ongoing Disparities. Nat. Rev. Cardiol. 17, 533-535.

Chuăng (2020). Social Contagion. Chuăng, http://chuangcn.org/2020/02/social-contagion (12 Oct. 2020).

Costanzo, Gianfranco et al. (2020). Indagine Nazionale CoVid-19 nelle strutture del sistema di accoglienza per migranti. Rome: Inmp, https://www.inmp.it/pubblicazioni/ Indagine_COVID-19_strutture_accoglienza.pdf (12 Oct. 2020).

Fernandes, Florestan (2008). A integração do negro na sociedade de classes. São Paulo: Globo.

Foster, John B. et al. (2011). The Ecological Rift. New York: Monthly Review Press.

Goes, Emanuelle et al. (2020). Desigualdades raciais em saúde e a pandemia da Covid-19. Trabalho, Educação e Saúde 18/3, 1-7. 
Gonçalves, Renata (2018). Quando a questão racial é o nó da questão social. Katálysis 21/3, 514-522.

Gravlee, Clarence (2020). Systemic Racism, Chronic Health Inequities, and COVID-19: A Syndemic in the Making?. American Journal of Human Biology 32/5, e23482.

Guijarro, Carlos et al. (2020). Riesgo de COVID-19 en españoles y migrantes de distintas zonas del mundo residentes en España en la primera oleada de la enfermedad. Revista Clínica Española, https://doi.org/10.1016/j.rce.2020.10.006.

Hallal, Pedro et al. (2020). SARS-CoV-2 Antibody Prevalence in Brazil: Results from two Successive Nationwide Serological Household Surveys. The Lancet 8/11, E-1390-e1398.

Hansson, Erik et al. (2020). Large Differences in Excess Mortality in March-May 2020 by Country of Birth in Sweden. PubMed, https://pubmed.ncbi.nlm.nih. gov/32619245.

Heringer, Rosana (2002). Desigualdades Raciais no Brasil. Cad. Saúde Pública 18, S57-S65.

Hou, Feng et al. (2020). Transitions into and out of Employment by Immigrants During the COVID-19 Lockdown and Recovery. Catalogue n. 45280001, Statistics Canada, https://www150.statcan.gc.ca/n1/pub/45-28-0001/2020001/article/00070-eng. htm (12 Oct. 2020).

Ibge (2019). Desigualdades Sociais por Cor ou Raça no Brasil. Rio de Janeiro: Ibge, https://biblioteca.ibge.gov.br/index.php/biblioteca-catalogo?view=detalhes\&id=2101681 (12 Oct. 2020).

Idos (2020). Dossier Statistico Immigrazione. Rome: Idos.

ILO (2018). Global Estimates on International Migrant Workers. Geneva: ILO, https:// www.ilo.org/wcmsp5/groups/public/---dgreports/---dcomm/---publ/documents/publication/wcms_652001.pdf (12 Oct. 2020).

Istat (2020a). Rapporto annuale 2020. Rome: Istat, https://www.istat.it/storage/rapporto-annuale/2020/Rapportoannuale2020.pdf (12 Oct. 2020).

Istat (2020b). Impatto dell'epidemia Covid-19 sulla mortalità totale della popolazione residente primo trimestre 2020. Rome: Istat, https://www.istat.it/it/files/2020/05/ Rapporto_Istat_ISS.pdf (12 Oct. 2020).

Laster Pirtle, Whitney (2020). Racial Capitalism: A Fundamental Cause of Novel Coronavirus (COVID-19) Pandemic Inequities in the United States. Health Education \& Behavior 47/4, 504-508.

Kerwin, Donald, Warren, Robert (2020). US Foreign-Born Workers in the Global Pandemic. Journal on Migration and Human Security, 1-19, https://doi.org/ $10.1177 / 2311502420952752$.

Kochhar, Rakesh (2020). Hispanic Women, Immigrants, Young Adults, Those with Less Education Hit Hardest by COVID-19 Job Losses, Pew Research, https://www.pewresearch.org/fact-tank/2020/06/09/hispanic-women-immigrants-young-adultsthose-with-less-education-hit-hardest-by-covid-19-job-losses (12 Oct. 2020). 
Kunst, Anton et al. (2020). Oversterfte tijdens de eerste zes weken van de corona-epidemie, CBS Statistische Trends, https://www.cbs.nl/nl-nl/achtergrond/2020/20/oversterfte-tijdens-de-eerste-zes-weken-van-de-corona-epidemie (12 Oct. 2020).

Mamelund, Svenn-Erik et al. (2019). The Association between Socioeconomic Status and Pandemic Influenza. Systematic Reviews 8/5, 1-6.

Moura, Clóvis (1988). Sociologia do Negro Brasileiro. San Paulo: Ática.

Novick, Michael (1995). White Lies, White Power. Monroe: Common Courage Press.

OECD (2020a). Managing International Migration Under COVID-19. OECD, https:// read.oecd-ilibrary.org/view/?ref=134_134314-9shbokosu5\&title=Managing-international-migration-under-COVID-19 (12 Oct. 2020).

OECD (2020b). What is the Impact of the COVID-19 Pandemic on Immigrants and their Children? OECD, http://www.oecd.org/coronavirus/policy-responses/whatis-the-impact-of-the-covid-19-pandemic-on-immigrants-and-their-childrene7cbb7de/ (12 Oct. 2020).

Oliveira, Roberta et al. (2020). Racial Inequalities and Death on the Horizon: COVID-19 and Structural Racism. Cadernos de Saúde Pública 39/9, 1-14.

Paixão, Marcelo et al. (2010). Relatório Anual das Desigualdades Raciais no Brasil. 2009-2010, Rio de Janeiro: Garamond, https://www.geledes.org.br/wp-content/ uploads/2014/05/Relat\%C3\%B3rio_2009-2010.pdf (12 Oct. 2020).

Papon, Sylvain, Robert-Bobée, Isabelle (2020). Une hausse des décès deux fois plus forte pour les personnes nées à l'étranger que pour celles nées en France en mars-avril 2020. Paris: INSEE, https://www.insee.fr/fr/statistiques/4627049\#documentation (12 Oct. 2020).

Prante, Franz et al. (2020). Decades of Tight Fiscal Policy Have Left the Health Care System in Italy III-Prepared to Fight the COVID-19 Outbreak. Intereconomics 55/3, 147-152.

Sage (2020). COVID-19 and Health Inequality. The Independent SAGE Report 21, https://www.independentsage.org/wp-content/uploads/2020/11/Inequalities-_i_SAGE_FINAL-draft_corrected.pdf (12 Oct. 2020).

Sanchez, Gabriella, Achilli, Luigi (2020). Stranded: The Impacts of COVID-19 on Irregular Migration and Migrant Smuggling. Florence: European University Institute, http:// hdl.handle.net/1814/67069.

Santos, Herbert et al. (2020). Necropolítica e reflexões acerca da população negra no contexto da pandemia da COVID-19 no Brasil. Ciência \& Saúde Coletiva 25, 4211-4224.

Singer, Merrill (1996). A Dose of Drugs, a Touch of Violence, a Case of AIDS: Conceptualizing the SAVA Syndemic. Free Inquiry in Creative Sociology 24/2, 99-110.

Singer, Merrill (2009). Introduction to Syndemics. San Francisco: John Wiley \& Sons. The Lancet (2017). Syndemics: Health in Context. The Lancet 389/10072, 881.

Valeriani, Giuseppe et al. (2020). Addressing Healthcare Gaps in Sweden during the COVID-19 Outbreak, Healthcare 8/4, 1-9. 
Wallace, Robert (2020). Dead Epidemiologists: On the Origins of COVID-19. New York: Monthly Review Press.

Wallace, Robert (2016). Big Farms Make Big Flu. New York: Monthly Review Press.

Wallace, Robert et al. (2016). Did Neoliberalizing West African Forests Produce a New Niche for Ebola? International Journal of Health Services 46/1, 149-165.

Wallace, Robert, Wallace, Rodrik (eds.) (2016). Neoliberal Ebola: Modelling Disease Emergence from Finance to Forest and Farm. Cham: Springer.

Zelner, Jon et al. (2020). Racial Disparities in COVID-19 mortality are Driven by Unequal Infection Risks. Clinical Infectious Diseases 72/5, e88-e95. 


\section{POVZETEK}

\section{KORONAKRIZA IN MIGRACIJE: PANSINDEMIJA IN NJEN VPLIV NA MIGRANTE Fabio PEROCCO}

Članek vpliv pandemije na zdravje in delovne razmere migrantov analizira na globalni ravni, a s posebnim poudarkom na zahodnih državah. Uvodoma obravnava ekološko družbeni izvor virusa SARS-CoV-2 (ob upoštevanju uničevanja okolja, krčenja gozdov, agroživilske industrije, množične urbanizacije oziroma vpliva kapitalizma na uničevanje narave), neenak vpliv pandemije na zdravje ljudi (obolevnost in smrtnost), povezan z družbenimi determinantami zdravja in sindemičnih pojavov, kakor tudi s Covidom-19 povezano rasno zdravstveno neenakopravnost kot posledico sistemskega rasizma in strukturne rasne neenakosti.

Izsledki študije kažejo, da so migranti iz različnih v članku opisanih razlogov utrpeli hude posledice, še zlasti pa so bili dovzetni za ekonomske in družbene učinke epidemije. Ob veliki izpostavljenosti virusu ter ranljivosti in dovzetnosti za okužbo so številne posledice, odvisne od njihovega družbenega in pravnega položaja, utrpeli tudi na trgu dela. Priseljenci so bili med družbenimi skupinami, ki so jih prekarnost, brezposelnost, podzaposlenost, slabše delovne razmere in revščina najbolj prizadeli; pogosto so bili bolj izpostavljeni in izkoriščani in v še bolj negotovem delovnem razmerju. Tudi prosilci za azil so bili zaradi svoje strukturne ranljivosti in neugodnega družbenega položaja tako zdravstveno kot družbeno bolj izpostavljeni epidemiji; sprejemni centri in begunska taborišča niso mogli zagotoviti zadostne fizične razdalje in javne zdravstvene oskrbe, njihov bivalni status je bil negotov, pravni položaj pa vse slabši, zato so bili pogosto prepuščeni sami sebi in se niso mogli svobodno gibati. Razmere so se naglo in dramatično slabšale tudi za migrante, ki so bili že na poti oziroma so se na pot odpravili med pandemijo. Pogosto so brez sredstev za preživetje, skoraj brez dostopa do socialnih služb, brez pozornosti javnosti in s povečanim tveganjem za izpostavljenost nehumanemu ravnanju oblasti obtičali v tranzitnih deželah, na mejnih prehodih in na poti. 